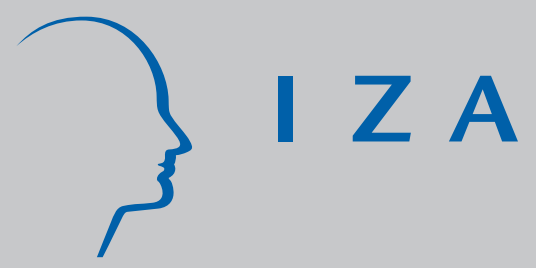

IZA DP No. 1220

Females' Willingness to Work and the Discouragement Effect of a Poor Local Childcare Provision

Maarten van Ham

Felix Büchel

J uly 2004 


\title{
Females' Willingness to Work and the Discouragement Effect of a Poor Local Childcare Provision
}

\author{
Maarten van Ham \\ OTB, Delft University of Technology \\ Felix Büchel $\dagger$ \\ Max Planck Institute for Human Development, \\ Technical University of Berlin, Free University of Berlin, \\ DIW Berlin and IZA Bonn
}

\section{Discussion Paper No. 1220 July 2004}

\author{
IZA \\ P.O. Box 7240 \\ 53072 Bonn \\ Germany \\ Phone: +49-228-3894-0 \\ Fax: +49-228-3894-180 \\ Email: iza@iza.org
}

\begin{abstract}
Any opinions expressed here are those of the author(s) and not those of the institute. Research disseminated by IZA may include views on policy, but the institute itself takes no institutional policy positions.

The Institute for the Study of Labor (IZA) in Bonn is a local and virtual international research center and a place of communication between science, politics and business. IZA is an independent nonprofit company supported by Deutsche Post World Net. The center is associated with the University of Bonn and offers a stimulating research environment through its research networks, research support, and visitors and doctoral programs. IZA engages in (i) original and internationally competitive research in all fields of labor economics, (ii) development of policy concepts, and (iii) dissemination of research results and concepts to the interested public.
\end{abstract}

IZA Discussion Papers often represent preliminary work and are circulated to encourage discussion. Citation of such a paper should account for its provisional character. A revised version may be available on the IZA website (www.iza.org) or directly from the author. 
IZA Discussion Paper No. 1220

July 2004

\section{ABSTRACT}

\section{Females' Willingness to Work and the Discouragement Effect of a Poor Local Childcare Provision}

We analyze the effects of regional structures on females' willingness to work as well as on the probability that non-employed women who are willing to work actually will engage in job search. Special permission was granted to link regional data to individual respondents in the German Socio-Economic Panel (SOEP). Results of a bivariate probit model correcting for sample selection show that high regional unemployment discourages women from entering the labor market. Further, findings indicate that women with young children are willing to work, but that women with young children and mothers who are unhappy with the regional childcare provision are the least likely to look for a job. These findings indicate that high institutional and spatial barriers discourage mothers from entering employment.

JEL Classification: R23, J13, J64

Keywords: female labor supply, job search, regional labor markets, childcare provision, bivariate probit model

Corresponding author:

Maarten van Ham

OTB Research Institute for Housing and Mobility Studies

Delft University of Technology

P.O. Box 5030

2600 GA Delft

The Netherlands

Email: m.v.ham@otb.tudelft.nl 


\section{In Memory of Felix Büchel, 1957-2004}

Felix Büchel was a tenured Senior Research Scientist (C3 position) at the Max Planck Institute for Human Development (Max-Planck-Institut für Bildungsforschung) in Berlin. He was affiliated as a Professor of Economics (Adjunct Professorship) at the Technical University Berlin, as a Professor of Sociology (Honorary Professorship) at the Free University of Berlin, and as a Research Professor with the German Socio-Economic Panel Study (SOEP) at the DIW Berlin.

Felix Büchel's research interests included applied labour economics, economics of education, population economics, and social policy research. Büchel served in various scientific boards and committees and published articles in journals such as Population Research and Policy Review, Ageing \& Society, Journal of Population Economics, Journal of Urban Economics, Applied Economics, Scottish Journal of Political Economy, Economics of Education Review, Journal of Marriage and the Family, Acta Sociologica, Early Childhood Research Quarterly, and International Journal of Manpower.

Courageously battling cancer, Felix Büchel continued his research until the very last moment before he passed away on July 12, 2004 at the age of 47.

An IZA Research Fellow since January 2002, Felix Büchel was one of IZA's most active members. He participated in several workshops and published a total of 11 IZA Discussion Papers. This paper was finished shortly before his death.

The members of IZA are saddened by Felix Büchel's passing and will cherish his important contributions in memory. 


\section{Introduction}

The spatial mismatch between where workers live and where jobs are located is considered an important cause of non-employment (Kain, 1968; Van Ham, 2002). Poor geographical access to suitable jobs is thought to negatively influence employment opportunities and labor market outcomes at the individual level (Hanson and Pratt, 1990). However, not all workers are equally disadvantaged by spatial barriers on the labor market. In the 1990 s, research into the effects of spatial barriers on female labor-force participation, in particular, made major advances (Preston and McLafferty, 1999). Most women face severe day-to-day space-time constraints because of their domestic workload, which limits the time available for work and getting to work (Hanson and Pratt, 1990; Pratt and Hanson, 1991, Büchel and Spieß, 2002). These constraints often present a serious geographical barrier to labor-force participation because they spatially restrict the opportunity set of available jobs (Van Ham, 2002). Other authors have suggested that geographical access to childcare facilities is an important factor determining access to employment opportunities for women with young children (Kwan, 1999; Van Dijk and Siegers, 1996; Van Ham and Mulder, 2004).

Although it is clear that poor access to employment opportunities leads to nonemployment or to employment with a poor fit between job requirements and education of the job-holder (Büchel and Van Ham, 2003), it is not clear exactly how this mechanism works. Studies on female labor-force participation often focus on the relationship between having a job and access to employment opportunities. The more jobs there are, the higher the probability of being employed. In general, these studies do not consider the important intermediate step of job search. Job search is a prerequisite for labor market participation (Mortensen, 1986) and is seen as the conceptual link between access to suitable employment and actually having a job (Van Ham et al., 2001). The higher the search intensity, and the more suitable jobs available, the more likely people are to find a suitable job. According to the discouraged worker hypothesis, the intensity of the job search itself is also influenced by 
access to suitable employment (Fisher and Nijkamp, 1987). It is assumed that people with poor labor market expectations can become discouraged and leave or fail to enter the labor force because the probability of finding a suitable job after a certain period of time is too low.

We assume that poor regional labor market conditions can have a discouraging effect on women at two phases of participation. In the first phase, they have to decide whether or not they want to participate on the labor market. It can be hypothesized that some of the women in the potential labor force who state that they do not want a paid job would in fact state otherwise if they had access to suitable employment. In the second phase, women who state that they are willing to work might become discouraged in their job search by poor labor market conditions. Examining these two phases will provide more of an insight into the size of the hidden labor force.

This article explores the extent to which the opportunity structure of the regional labor market has a double-edged effect on female labor-force participation in the Western part of Germany. It is hypothesized that the opportunity structure influences both the decision to enter the labor market (willingness to take up a paid job) and the probability that those willing to work will actually engage in job search. Aspects of the regional labor market considered are the female unemployment rate and, in particular, the availability of childcare. The hypotheses were tested using individual level data from the 2001 wave of the German SocioEconomic Panel (SOEP). This representative dataset, which is easily accessible to the scientific community, includes detailed information on the individual and household characteristics of more than 22,000 respondents. For this article, two unique features of the SOEP data were used. First we utilized of a set of variables allowing the hidden labor market reserve to be identified. Second, we were given special permission to link regional labor market characteristics to individual respondents. The effect of the regional opportunity structure on female employment was estimated using a bivariate probit model that corrects for sample selection. 


\section{Spatial restrictions and discouragement: the role of the regional labor market situation}

\section{and childcare provision}

In this paper, we argue that the job search process must be examined more closely if we are to gain a better understanding of the link between characteristics of the regional labor market and female labor-force participation. Job search is the conceptual link between access to suitable employment and actually having a job (Van Ham et al., 2001). The intensity of job search can be seen as a continuum ranging from 0 to 1 . Those with the highest search intensity are most likely to find a job (Stigler, 1961, 1962; Lippman and McCall, 1976; Kiefer and Neumann, 1989; Devine and Kiefer, 1991). In our view, the group of women with search intensity 0 is very heterogeneous, consisting of women who are not looking for a job because they do not want to work as well as women who are no longer looking for work because they have become discouraged. We consider this distinction very important for understanding female labor-force participation.

According to the discouraged worker hypothesis (Fisher and Nijkamp, 1987; Van Ham et al., 2001), people with poor labor market expectations become discouraged and leave or fail to enter the labor force because the probability of finding a suitable job after a certain period of time is too low. Poor labor market prospects, leading to discouragement, may result from individual characteristics, either real or ascribed. Discouragement can also be caused by the structure of the labor market (Van Ham et al., 2001). In order to understand how poor access to employment opportunities causes discouragement and, in turn, influences female laborforce participation, two phases of participation have to be distinguished. In the first phase, women decide whether or not they are willing to take up a paid job. In principle, all women are part of the potential labor force; however, only those willing to enter paid employment are part of the active labor force and therefore 'at risk' of actually being engaged in job search. The second phase is the job search of those who are willing to work and are, therefore, in the 
active labor force. We argue that discouragement as a result of poor regional labor market conditions can take place at either phase of participation.

A key question as regards the first phase is what determines whether women are willing to work. Not all women want to have a paid job. Some women prefer to be full-time housewives and mothers, especially if they have (young) children. However, it is also widely recognized that women face numerous restrictions that make it difficult for them to take up paid employment, particularly if they have children (see, for example, Hanson and Pratt, 1995). It is very likely that some women would like to work if they considered it a possibility, but state that they do not want to work because they perceive the probability of actually getting a job to be unrealistically low.

Poor access to employment opportunities may be expressed by a high regional unemployment rate, which indicates a mismatch between supply and demand on the regional labor market (Simpson, 1992). We therefore expect women living in regions with a high unemployment rate to be less likely to express willingness to work (be part of the active labor force) than women in regions with a low unemployment rate (Büchel and Van Ham, 2004). For women with young children, poor geographical access to childcare may also lead to discouragement. Several authors have asserted that geographical access to childcare facilities is an important factor determining whether or not women with young children have access to certain job locations (Michelson 1985, 1988; Tivers 1985, 1988; Hanson and Pratt 1988, 1990; England 1996a, 1996b; Gilbert 1998; Kwan 1999). This implies that, for many mothers, good geographical access to childcare facilities is a precondition for access to employment opportunities. When childcare is not available, this may lead to discouragement. We therefore expect mothers with poor access to childcare facilities to be less likely to express willingness to work than mothers with good access to childcare facilities.

Discouragement may also influence participation in the job search phase among those women who are willing to have a paid job (and are therefore in the active labor force). Even 
when women decide to participate on the labor market, their domestic workload in combination with the presence of young children can be expected to limit their opportunities to search for a suitable job. Based on the above, we can formulate two hypotheses concerning the influence of the regional opportunity structure on the probability that women who are willing to work will actually look for a job. First, we expect high regional unemployment to negatively influence the probability that women willing to work are actually looking for a job. A high regional unemployment level indicates fierce competition on the regional labor market, which might discourage women in their job search. Second, we expect mothers with poor access to childcare to be less engaged in job search because it is difficult for them to combine looking for (and holding) a job with caring for small children.

\section{Data and methodology}

Data

The individual level data used in this paper were taken from the 2001 wave of the German Socio-Economic Panel (SOEP) with information on 22,351 respondents. This database is administered by the German Institute for Economic Research (DIW) in Berlin (see Wagner et al., 1993; SOEP Group, 2001, for details). The analyses were restricted to women aged between 18 and 59 who were living in the Western part of Germany. We excluded students, trainees, and respondents who reported that they were unable to work due to a disability. Since we are interested in off-the-job search only, we also excluded respondents who reported having a paid job in the 7 days prior to the interview. Following this selection procedure, the data set comprised 1281 non-employed female respondents.

To test our hypotheses, we need to analyze both willingness to work (being part of the active labor force) and search activity among those willing to work. The German SocioEconomic Panel includes some unique variables that make it possible to identify the hidden labor force reserve, i.e. those who are willing to work in principle, but who are currently not 
looking for a job and therefore do not report unemployed status. According to our definition, all 1281 non-employed women in our sample are members of the potential labor force. Those who are willing to work (the involuntarily unemployed and members of the hidden labor force reserve) are part of the active labor force. To make this distinction, we drew on the responses to a question posed to non-employed respondents: "Do you intend to engage in paid employment (again) in the future?" The women who stated "No, definitely not" were coded as not willing to work and categorized as not being in the active labor force.

For the second part of the analysis we had to define active job search among those willing to work. This was done by drawing on responses to the question "Have you actively looked for work within the last four weeks?" All non-employed women who answered "Yes" were defined as being actively engaged in job search. The selection procedure based on these definitions of the active labor force and active job search results in a total of 1281 female respondents in the active labor force (willing to work), of whom 683 were engaged in active job search.

Besides the individual level data from the SOEP respondents, information on regional labor market characteristics was also needed. For this purpose, the 2001 regional data for the 75 West German spatial planning regions (Raumordnungsregionen) were obtained from the German Federal Office for Building and Regional Planning (Bundesamt für Bauwesen und Raumordnung, 2002). Using the Raumordnungsregion number for the SOEP respondents' place of residence as a key variable, we were able to link regional data to individual data. We gratefully acknowledge the invaluable help of the data protection officer responsible for the SOEP data, who granted us special permission to link these two sets of data. Two regional level variables were used in the analyses: number of unemployed women per 1000 women aged 15-65, and number of childcare slots per 100 children below 7 years of age. Table 1 presents the variable summary statistics and definitions of the variables for the whole sample (willingness to work equation) and the sample of those willing to work (job search equation). 
Table 1 Variable summary statistics and definitions

\section{Willingness to work equation $(\mathrm{N}=1281)$}

Dependent: willing to work $(1=$ willing $)$

0.533

0.499

$0-1$

Age (in years)

42.795

10.946

$18-59$

Education (in years)

10.924

$2.252 \quad 7-18$

Work experience $^{\mathrm{a}}(1=$ had a job $)$

0.073

$0-1$

Partner $(1=$ partner present $)$

0.907

$0-1$

Number of child(ren) up to 7 years

0.370

$0.654 \quad 0-3$

Age of youngest child under 7 years

3.594

0.861

$0-6$

Unhappy with household income ${ }^{\mathrm{b}}(1=$ unhappy $)$

0.184

$0-1$

$\operatorname{Disabled}^{\mathrm{c}}(1=$ disabled $)$

0.071

$0-1$

Foreigner $^{\mathrm{d}}(1=$ foreigner $)$

0.231

$0-1$

Unhappy with childcare provision ${ }^{\mathrm{e}}(1=$ unhappy)

0.231

$0-1$

Very unhappy with childcare provision ${ }^{\mathrm{e}}(1=\mathrm{unh})$

0.030

$0-1$

Childcare slots per 100 children $<7$ y. in region ${ }^{\mathrm{f}}$

56.786

7.924

$39.4-82.7$

Unemployed women per 1000 in region $^{\mathrm{g}}$

50.098

14.305

23-97

\section{Search equation $(N=683)$}

Dependent: search in last 4 weeks $(1=$ search $)$

0.246

0.431

$0-1$

Age (in years)

38.089

$9.555 \quad 18-59$

Education (in years)

11.314

2.375

$7-18$

Work experience $^{\mathrm{a}}(1=$ had a job $)$

0.103

$0-1$

Partner $(1=$ partner present $)$

0.868

$0-1$ 


\begin{tabular}{|c|c|c|c|}
\hline Number of child(ren) up to 7 years & 0.490 & 0.703 & $0-3$ \\
\hline Age of youngest child under 7 years & 3.615 & 0.981 & $0-6$ \\
\hline Unhappy with household income $^{\mathrm{b}}(1=$ unhappy $)$ & 0.231 & & $0-1$ \\
\hline $\operatorname{Disabled}^{\mathrm{c}}(1=$ disabled $)$ & 0.050 & & $0-1$ \\
\hline Unhappy with childcare provision $^{\mathrm{e}}(1=$ unhappy $)$ & 0.286 & & $0-1$ \\
\hline Very unhappy with childcare provision $(1=$ unh $)$ & 0.040 & & $0-1$ \\
\hline Childcare slots per 100 children $<7$ y. in region ${ }^{\mathrm{f}}$ & 57.065 & 8.477 & $39.4-82.7$ \\
\hline Unemployed women per 1000 in region $^{\mathrm{g}}$ & 49.838 & 15.107 & $23-97$ \\
\hline
\end{tabular}

${ }^{a}$ Respondents are defined to have work experience if they have previously had a job for at least 1 year

${ }^{\mathrm{b}}$ Those categorized as unhappy with their household income scored $0-4$ on a scale from 0 'totally unhappy' to 10 'totally happy' (Question 'How satisfied are you today with your household income?')

${ }^{\mathrm{c}}$ Respondents are defined as disabled if they state that their health situation 'strongly' impedes their performance of daily activities

${ }^{\mathrm{d}}$ Respondents are defined as foreigners if they do not have German nationality

${ }^{\mathrm{e}}$ Those categorized as very unhappy with childcare scored 0-3 and those categorized as unhappy with childcare scored 4-8 on a scale from 0 'totally unhappy' to 10 'totally happy' (Question 'If you have small children, how satisfied are you today with the childcare available?')

${ }^{\mathrm{f}}$ Number of childcare slots per 100 children up to 6 years old, regional level data (measured on 01.01.1999)

${ }^{\mathrm{g}}$ Number of unemployed women per 1000 women aged 15-65, regional level data (measured on 01.01.2001) 
Source: Own calculations based on SOEP data, matched with regional data from the German Federal Office for Building and Regional Planning (both for 2001, West Germany only).

\section{Methodology}

Theoretical considerations have two important implications for the methodology used. First, the cases in our model need to be clustered by region of residence (the 75 West German Raumordnungsregionen). The data include both individual level and regional characteristics, and there is more than one respondent per region in our sample. Ignoring the nested nature of the data would violate the standard assumption of independence of observations that underlies traditional regression models. Clustering the data by region in the model used solves this problem (Statacorp, 2001).

Second, we have to analyze the two mechanisms of willingness to work and being engaged in active job search in a single model, because the two mechanisms cannot be seen separately. The relationship between regional characteristics of the labor market and the probability that women are engaged in job search is not straightforward (Van Ham et al., 2001). Those willing to work and therefore in the active labor force form a selective group, and it can be assumed that the selection process is related to our dependent variable (being engaged in active job search). If the regional labor market situation is poor, unwillingness to work may be a strategy deliberately chosen to avoid becoming unemployed. Because those most likely to be unemployed are least likely to look for a job (Van Ham et al., 2001), analyzing job search behavior while restricting the sample to those in the active labor force could lead to biased results. In the present study, we account for sample selection bias by employing a variant of Heckman's (1979) two-step selection model. In the first step, the probability of willingness to work (be part of the active labor force) is analyzed. In the second step, the probability of being engaged in job search is analyzed for those willing to work. Because the dependent variables in both the selection and the employment model are binary, a 
bivariate probit model with sample selection is proposed, following Van de Ven and Van Praag (1981). ${ }^{1}$ This maximum-likelihood probit model with sample selection provides consistent, asymptotically efficient estimates for all parameters in the model (Statacorp, 2001).

When specifying a two-step model, one has to ensure the model is properly identified (Manski, 1995). Strictly speaking, our model is basically identified by functional form because the bivariate probit model is non-linear. However, we decided to adopt an additional strategy in order to avoid multicollinearity problems and to ensure identification of the model. The key element of this strategy is to select at least one instrument variable that affects only the decision to be part of the active labor force, and not the probability of being engaged in job search. The difficulty here is that we can expect very similar factors to influence both the probability that people are willing to work and the probability that they are actively engaged in job search, since both selection processes are likely to be very similar. Since a formal econometric test that could indicate the correct specification of the model is not available, any argument as to why specific variables are expected to influence one equation and not the other has to be of a substantive, theoretical nature. We chose to use identical sets of regressors in both equations (because of the arguments given above), with the exception of the 'foreigner' variable, which is only used in the active labor force equation. It is well-known that nonnative women are highly overrepresented in the population of economically inactive females (Büchel and Van Ham, 2004). On the other hand, there is no reason to expect that non-native

\footnotetext{
${ }^{1}$ The two-step selection model is often estimated by obtaining the inverse Mill's Ratio
} from a first stage probit, and entering it into the second stage equation. As noted by Van de Ven and Van Praag (1981), if the dependent variable in the second stage equation is binary, the error term is not normally distributed; a two-stage approach to this problem would therefore yield only approximate results. 
women who want to work make less effort to attain this goal than their German counterparts. To test this assumption, we ran a model including the 'foreigner' variable as a regressor in a single probit search equation. This test produced very similar results to the search equation with sample selection shown in the lower part of Table 2, and yielded no significant effect of non-native status (not shown in Tables).

\section{Results}

Table 2 presents the results of the full bivariate probit model with sample selection. First of all, the coefficient $\rho(0.860)$ is significantly different from zero, signifying that there is a positive correlation between the error terms of the willingness to work and the search equations. This indicates that unmeasured respondent characteristics influence both the probability of willingness to work and the probability of being engaged in job search, making it necessary to correct for (self-)selection. To give a substantive interpretation, the results indicate that women with unmeasured characteristics (e.g. high motivation to be economically active) are more likely to state that they want to work, and are also more likely to be engaged in job search than others.

Table 2 Determinants of willingness to work and of off-the-job search for those willing to work (bivariate probit model with sample selection)

\section{Coefficient $\quad$ Robust Std. Error ${ }^{1}$}

\section{Willingness to work equation $(\mathrm{N}=1281)$}

Age (in years)

Age squared

Education (in years)

Work experience
0.014

$-0.001 * * *$

$0.116 * * *$

$0.597 * * *$

0.129 
Number of child(ren) up to 7 years

$-0.027$

0.079

Age of youngest child under 7 years

0.073

0.041

Unhappy with household income

$0.388 * * *$

0.098

Disabled

$-0.131$

0.163

Foreigner

$-0.281$

Unhappy with childcare provision

$-0.153$

0.107

Very unhappy with childcare provision

0.135

0.231

Childcare slots per 100 children $<7$ y. in region

0.007

0.009

Unemployed women per 1000 in region

$-0.007 *$

0.004

Constant

0.652

0.962

\section{Search equation $(\mathrm{N}=683)$}

Age (in years)

Age squared

Education (in years)

Work experience

Partner

Number of child(ren) up to 7 years

Age of youngest child under 7 years

Unhappy with household income

Disabled

Unhappy with childcare provision

Very unhappy with childcare provision

Childcare slots per 100 children $<7$ y. in region
$-0.071$

0.037

0.000

0.000

$0.087 * * *$

0.020

$0.884 * * *$

0.137

$-0.703$

$* * *$

0.180

$-0.271$

$* * *$

0.086

$0.154 * * *$

0.059

$0.643 * * *$

0.116

$-0.475 *$

0.229

$-0.261 *$

0.139

$-0.809$

0.412

0.001

0.007 
Log Likelihood $=-979.247$

Correlation Coefficient $(\rho)^{2}$

$*=\mathrm{p}<0.10 ; * *=\mathrm{p}<0.05 ; * * *=\mathrm{p}<0.01$

${ }^{1}$ Standard errors adjusted for clustering on Raumordnungsregionen (spatial planning regions)

${ }^{2}$ Wald test for independent equations: chi-square $=4.47, \mathrm{df}=1, \mathrm{p}=0.035$

Source: Own calculations based on SOEP data, matched with regional data from the German Federal Office for Building and Regional Planning (both for 2001, West Germany only).

\section{Willingness to work equation}

The results of the willingness to work equation are presented in the top half of Table 2 . The dependent variable indicates whether respondents are willing to have a paid job (1) or not (0). The results obtained for the control variables are in line with the existing literature and are, therefore, discussed only briefly.

The probability of willingness to work is negatively related to age: with increasing age, the probability that women are willing to have a paid job decreases. As expected, the probability that women are willing to work increases with their number of years in education. The more people invested in their formal human capital, the more likely they are to want to realize a return on this investment in the form of a wage or salary (see Becker, 1962, on human capital theory). Also in line with human capital theory, the probability of willingness to work is highest for those with previous work experience.

Women with a partner are less likely to be willing to have a paid job than single women. This often reflects the outcome of a work specialization decision within the 
household. Note that this result is partly controlled for monetary aspects, since satisfaction with household income was controlled separately. Mothers with children under the age of 7 are not significantly underrepresented among those willing to have a paid job. This noteworthy results reflects the strong employment orientation of young West German women, most of whom are educationally well prepared for an occupational career. With increasing age of the youngest child, non-employed women become more likely to state that they want a paid job.

Women who report being unhappy with their household income are more likely to express willingness to work. Disabled women are not significantly underrepresented among those who state that they are willing to work. Non-native women are less likely to express willingness to work. On the one hand, this may reflect culturally differential labor market behavior. On the other hand, the reduced labor market participation of non-native women could also indicate discouragement effects caused by fewer labor market opportunities being open to this group. Dissatisfaction with the local childcare provision has no significant effect on willingness to work (for women with young children).

Of the two regional variables included in the equation, only the number of unemployed women per 1000 women has a significant impact on labor-force participation. The probability of being in the active labor force decreases as the regional level of female unemployment increases. The fact that women in regions with poor labor market prospects more often state that they do not want to work indicates that these women are discouraged: they say they do not want to work because they do not believe they have a realistic chance of actually getting a paid job.

\section{Search equation}

The results of the search equation are given in the bottom half of Table 2 . The dependent variable indicates whether those respondents who are willing to work were actively engaged 
in job search (1) or not (0). The sample is restricted to those non-employed women who stated that they are willing to work. Again, the results obtained for the control variables are in line with the existing literature and are, therefore, discussed only briefly.

As expected, age has a negative effect on the probability of being engaged in job search. This result is in line with the discouraged worker hypothesis, which suggests that groups with poor employment prospects (e.g., older, non-employed women) are less likely to be engaged in job search, even if they indicate that they would like to work.

Furthermore, the probability of being engaged in job search increases with the number of years in education. This indicates brighter employment prospects for the better educated. Similarly, women with work experience are more likely to be engaged in job search.

Women with a partner are less likely to be engaged in job search than singles. This is consistent with the expectation of a dual job search being more difficult to accomplish than a single job search within the male breadwinner model (Büchel and Battu, 2003). The presence of children under 7 years in the household strongly decreases the probability that a woman will be actively looking for work. Thus, although mothers with young children often express the desire to work (see results of the willingness to work equation), they are far less active in trying to realize their plans than women without young children. This indicates that there are high (institutional) barriers to job search (and hence employment) for mothers with young children. However, the probability of being engaged in job search increases with the age of the youngest child - another well-known pattern. In other words, our results suggest that mothers with very young children would like to work, but do not look for a paid job because it is difficult to combine caring for a young child with looking for a job. As the child grows older, it becomes easier to combine these two tasks.

In line with our expectations, the probability of being engaged in job search is highest for those non-employed women who state that they are unhappy with their household income. Disabled women are underrepresented among those engaged in job search. This may reflect 
discouragement resulting from discrimination. The two characteristics of the regional labor market included in the analysis have no significant effect on job search.

The presence of young children in the household and dissatisfaction with the local childcare provision has a significant negative effect on job search. These findings are especially relevant, because the results of the willingness to work equation indicate that mothers with these characteristics are no less willing to work than others. These results suggest that, for women with young children, discouragement effects may bar the route to employment an early stage. Finally, it should be noted that subjective dissatisfaction with the local childcare provision is much more relevant to the ways-to-work processes analyzed in the present paper than the objective number of childcare slots available in the region. This shows that problems relating to the compatibility of work and family life always have to be solved within a restricted local environment.

\section{Conclusions}

A major finding of the present analysis is that mothers with young children are no less willing to work than other females, even if the regional childcare provision is poor and they are dissatisfied with the quality of the local childcare situation. However, this rather positive message is tainted by the other major finding, which indicates that women with young children who are dissatisfied with the quality of the local childcare situation are significantly less likely to try to enter paid employment by engaging in active job search. Family and labor market policy should actively combat this discouragement effect, which deters young mothers at an early stage in the transition to work. The finding that the density of regional childcare provision is less important than its perceived quality indicates that this is genuinely a task for politicians on the municipal level. 
Acknowledgements - Maarten van Ham is grateful to the Max Planck Institute for Human Development, Berlin, Germany, for the financial support provided during a two-month research period as a guest scientist in 2003. Maarten van Ham worked on this paper while at the Amsterdam study centre for the Metropolitan Environment (AME), University of Amsterdam.

\section{References}

Becker, G. (1962) Human capital: a theoretical and empirical analysis. Journal of Political Economy, 70, 9-46.

Büchel, F. \& Battu, H. (2003) The theory of differential overqualification: Does it work? Scottish Journal of Political Economy, 50 (1), 1-16.

Büchel, F. \& Spieß, C.K. (2002) Form der Kinderbetreuung und Arbeitsmarktverhalten von Müttern in West- und Ostdeutschland. [Childcare Arrangements and Mothers' Labor Market Participation in West and East Germany]. Report on behalf of the Federal Ministry for Family Affairs, Senior Citizens, Women and Youth. Stuttgart: W. Kohlhammer, Vol. 220 of the Ministry's Series, 2002, 108 p.

Büchel, F. \& Van Ham, M. (2003) Overeducation, regional labour markets and spatial flexibility. Journal of Urban Economics, 53, 482-493.

Büchel, F. \& Van Ham, M. (2004) Unable or unwilling to work? Spatial, institutional and socio-economic restrictions to females' labor market access. IZA Discussion Paper No. 1034, Bonn.

Bundesamt für Bauwesen und Raumordnung [BBR; German Federal Office for Building and Regional Planning] (2002) Aktuelle Daten zur Entwicklung der Städte, Kreise und Gemeinden. Ausgabe 2002 [Current Data on the Development of Cities, Districts and Municipalities. 2002 Edition]. BBR: Bonn. 
Devine, T.J. \& Kiefer, N.M. (1991) Empirical labour economics: the search approach. Oxford University Press: New York.

England, K. (1996a) Mothers, wives, workers: The everyday lives of working mothers, in England, K. (Ed) Who Will Mind the Baby? pp. 109-122. Routledge. London.

England, K. (1996b) Who will mind the baby?, in England, K. (Ed) Who Will Mind the Baby? pp. 3-19. Routledge. London.

Fisher, M.M. \& Nijkamp, P. (1987) Spatial labour market analysis: relevance and scope. In M.M. Fisher \& P. Nijkamp (Eds.), Regional Labour Markets (pp. 1-36). Amsterdam: North Holland.

Gilbert, M.R. (1998) "Race," space, and power: the survival strategies of working poor women. Annals of the Association of American Geographers, 88, 595-621.

Hanson, S. \& Pratt, G. (1988) Spatial dimensions of the gender division of labour in a local labour market. Urban Geography, 9, 180-202.

Hanson, S. \& Pratt, G. (1990) Geographic perspectives on the occupational segregation of woman. National Geographic Research, 6, 376-399.

Hanson, S. \& Pratt, G. (1995) Gender, work and space. London: Routledge.

Heckman, J. (1979) Sample selection bias as a specification error. Econometrica, 47, 153161.

Kain, J. (1968) Housing segregation, negro employment, and metropolitan decentralization. Quarterly Journal of Economics, 82, 175-197.

Kiefer, N.M. \& Neumann, G.R. (1989) Search models and applied labour economics. Cambridge: Cambridge University Press.

Kwan, M. (1999) Gender and individual access to urban opportunities: a study using spacetime measures. Professional Geographer, 51, 210-227.

Lippman, S.A. \& McCall, J.J. (1976) The economics of job search: a survey. Economic Inquiry, 14 (June), 155-189. 
Manski, C.F. (1995) Identification problems in the Social Sciences. Harvard University Press. Cambridge, MA.

Michelson, W. (1985) From sun to sun: Daily obligations and community structure in the lives of employed women and their families. Rowman and Allanheld. Totowa, NJ.

Michelson, W. (1988) Divergent convergence: The daily routines of employed spouses as a public affairs agenda, in Andrew, C. and Milroy, M. (Eds) Life Spaces: Gender, Household, Employment. pp. 81-101. University of British Columbia Press. Vancouver. Mortensen, D.T. (1986) Job search and labor market analysis. In O. Ashenfelter \& R. Layard (Eds.), Handbook of Labor Economics (pp. 849-919). Amsterdam: North-Holland.

Pratt, G. \& Hanson, S. (1991) Time, space, and the occupational segregation of women: a critique of human capital theory. Geoforum, 22, 149-157.

Preston, V. \& McLafferty, S. (1999) Spatial mismatch research in the 1990s: progress and potential. Papers in Regional Science, 78, 387-402.

Simpson, W. (1992) Urban structure and the labour market: worker mobility, commuting and underemployment in cities. Oxford: Clarendon Press.

SOEP Group (2001) The German Socio-Economic Panel (SOEP) after more than 15 years Overview, in Holst, E., Lillard, D.R. and DiPrete, T.A. (Eds.) Proceedings of the 2000 Fourth International Conference of German Socio-Economic Panel Study Users (SOEP2000), Vierteljahrshefte zur Wirtschaftsforschung, 70, 7-14.

StataCorp (2001) Stata Statistical Software: Release 7.0. College Station, TX: Stata Corporation.

Stigler, G.J. (1961) The economics of information. Journal of Political Economy, 69, 213225.

Stigler, G.J. (1962) Information in the labor market. Journal of Political Economy, 70, 94105. 
Tivers, J. (1985) Women attached: The daily lives of women with young children. Croom Helm. London.

Tivers, J. (1988) Women with young children: Constraints on activities in the urban environment, in Little, J., Peake, L. and Richardson, P. (Eds) Women in Cities: Gender and the Urban Environment. pp. 84-97. New York University Press. New York.

Van de Ven, W.P.M.M. \& Van Praag, B.M.S. (1981). The demand for deductibles in private health insurance: a probit model with sample selection. Journal of Econometrics, 17, $229-252$.

Van Dijk, L. \& Siegers, J. (1996) The effect of the supply of subsidized day-care facilities on female labor supply. Labor: Review of Labor Economics and Industrial Relations 10, $559-582$.

Van Ham, M., Mulder, C.H. \& Hooimeijer, P. (2001). Local underemployment and the discouraged worker effect. Urban Studies, 38, 1733-1751.

Van Ham, M. (2002). Job access, workplace mobility, and occupational achievement. Delft: Eburon.

Van Ham, M. \& Mulder, C.H. (2004) Geographical access to childcare and mothers' laborforce participation. Forthcoming in Journal of Economic \& Social Geography (TESG).

Wagner, G., Burkhauser, R.V. \& Behringer, F. (1993) The English language public use file of the German Socio-Economic Panel Study. In: The Journal of Human Resources, 28, $429-433$. 